Barbara Lewandowska-Tomaszczyk, State University of Applied Sciences in Konin, Poland

DOI: 10.17951/Ismll.2020.44.1.11-26

\title{
Spaces of Meanings and Translators' Identities
}

\begin{abstract}
The focus of the paper is the analysis of translators' identities as expressed in Polish-to-English and English-to-Polish translations understood in terms of informed choices from spaces of meanings. The first part of the paper deals with the relation of approximate correspondences between thought and reality on the one hand and between thought, image, linguistic system and cultural emotionality type on the other. The concept of semantic approximation in communication, introduced in Lewandowska-Tomaszczyk $(2010,2012)$ is shown to be conditioned by cognitive categorization problems of the language user, as well as a conscious choice of the syntactic structure and meanings in discourse. The conscious choices from meaning spaces are motivated by the translator's subjective intentions on the one hand as well as constraints imposed by the Target Language systems (displaced equivalence patterns), limitation on the translator's linguistic repertory and by Source Culture and Target Culture models and conventions. In the second part of the study an interpretation is proposed of semantic and cultural SL and TL similarities, meaning displacement and reconceptualization in monolingual and intercultural communication and translation to account for the translator's linguistic and cutural identity dynamics, with a varying emotionality message. It is illustrated by examples of Polish-to-English and English-to-Polish translations.

Keywords: cultural identity, emotions, English, linguistic identity, meaning displacement, Polish, reconceptualization, translator
\end{abstract}

\section{Introduction}

In order to analyse translators' contributions to language and culture and identify properties which define translation as informed choices from spaces of meanings one needs to examine primarily a relation between the surrounding world, human approximate perception and thoughts about external and self-reflected phenomena as well as the position and function of language understood in terms of its meanings and structures.

\section{Asymmetries between the world, thought, and language}

The relationship between the world, thought, and language is not fully symmetric (Dawkins, 2005). Human beings perceive a fairly narrow range of reality, constrained

Barbara Lewandowska-Tomaszczyk, Katedra Badań nad Językiem i Komunikacją, Państwowa Wyższa Szkoła Zawodowa w Koninie, ul. Przyjaźni 1, 62-510 Konin, barbara.lewandowska-tomaszczyk@konin. edu.pl, http://orcid.org/0000-0002-6836-3321 
predominantly by their neurophysiology, while language portrays the outside world in terms of this partial perception and meaning approximation (Lewandowska-Tomaszczyk, 2017a). This perceptual and - as a consequence - conceptual approximation - is rooted in ontological and epistemological vagueness, either underdetermined by their very character, for which no exact definition exists (Sossinsky, 1986) or else such meanings are either inaccessible, for various reasons, or volitionally disregarded. Furthermore, comprehension and interpretation of linguistic meanings are always related to an interpretive multiplicity in language, rooted in and originating from a limiting nature of particular properties of world languages as well as the nature of verbal interaction and its contextual conditioning.

One of the subjects of philosophical theorizing with regard to perception and language relates to the phenomenon of effability i.e., the possibility of expressiing human experiences and thoughts in a language. Katz's Principle of Effability (1978) proposes that every thinkable thought in natural language can be encoded and expressed by a sense of some sentence in language, however this idea does not find satisfactory support in today's research (e.g., Sperber \& Wilson, 1986). Language typological parameters, which limit the expression of some of human thoughts and feelings, also act as a constraining parameter. Some of the ontological categories which exist are verbally marked and can be expressed in a number of languages, while some others are absent or left non-verbalized in the system (as e.g., the category of grammatical gender). Structural ambiguities typical of particular linguistic systems such as e.g., syntactic or grammatical homonymy between Agent and Patient in Polish, various pragmatic ambiguities, etc., as well as cultural communication differences such as between lower-context and higher context cultures $^{1}$ (e.g., American vs. British English respectively), which require higher or lower contribution of varying portions of situational context to interpret language, contribute to the vagueness and indeterminacy of interactionally conveyed meaning.

\section{Meaning displacement and translational re-conceptualization}

Translation, in cognitivist terms, can be conceived of as re-conceptualization of a Source Language message to a Target Language in its context and situation. The term re-conceptualization (proposed and developed in LewandowskaTomaszczyk, 2010), denoting all the transformations that are brought about as a consequence of using different systems of linguistic structures and meanings, is partly dictated by different construal parameters (Langacker, 1987, 1991) in the

1 The distinction between high-context and low-context cultures was first introduced by the anthropologist Edward T. Hall (1989/1976). In high-context cultures the rules of communication are not explicitly stated in language but are transmitted through the use of contextual clues such as prosodic properties of voice, body language, or sociolinguistic markers (age, gender, status, etc.). Low-context cultures require more direct verbal communication to properly understand a message, as the context alone does not provide sufficiently explicit information on the meaning transferred by the speaker. 
Target as contrasted with the Source Language form (TL grammar and meaning structures), different contexts (author/speaker - i.e., translator, time, place, addressee - TL audience), but also conditioned by subjective knowledge and preferences of the translator. The translator selects or devises particular TL forms, which do not profile the same entities, i.e., are not instrumental in the identification of the same figures against the identical base ground (Langacker, 1987, 1991). As discussed in Lewandowska-Tomaszczyk (2010), the translators' and their readers' mental spaces are populated by characters bearing some semblance to the original $S L$ ones, interacting in ways which remind us of the SL interactions, but clearly re-constructed. The TL words and (fully semanticized) constructions give a new perspective, profile different parts of the base contents and make salient the - not necessarily identical - elements and parts of the original scenes. The translated text then is a blended outcome of the original SL forms and meanings and fully native TL forms and their semantics.

\section{Comparing emotions: Commensurability degrees}

Languages vary and to discuss ways of rendering a SL message in a TL one needs to consider roots and paths of linguistic diversification. Linguistic systems correspond to one another to different degrees. Their commensurability, as Lakoff (1987) names it, involves four kinds of identification criteria: (1) truth-conditional criteria (classical translatability), (2) criteria of use, (3) framing criteria judged in terms of particular Idealized Cognitive Models, (4) conceptual organization criteria. These criteria are related to the cognitive concept of a construal of the scene, which presents the content of the scene as portrayed by a relevant syntactic structure. Language systems at large are typically only partly commensurable, i.e., "calibrated", and the translator's task is to find such TL equivalents that would most effectively bridge the incommensurability gap between the TL and SL systems.

\subsection{Emotions cross-culturally}

The fundamental assumption of a cross-cultural study of emotion concepts in Polish and English (Lewandowska-Tomaszczyk \& Wilson, 2013; Wilson \& Lewandowska-Tomaszczyk, 2017) is that the conceptual structure of emotions comprises clusters of emotions that have a closer or more distant proximity within conceptual space. This approach, rooted in Cognitive Linguistcs findings, opposes the viewpoint that emotions are discrete entities that function independently of other emotions. As proposed in Wilson and Lewandowska-Tomaszczyk (2018) the meaning of each individual emotion is determined by both intra- and intercluster relationships, as well as dynamic interactions between these. A prototypeperiphery structure of emotion meanings is similar to other, more concrete concepts. These clusters are further characterised by a graded structure and fuzzy boundaries. A major structural element that determines the meaning of individual 
emotions within clusters is the breadth of conceptual space. Another potential influence on the conceptual space within clusters is lexical content A language that has a richer lexicon for a certain emotion cluster is likely to have a higher degree of granularity for that cluster. By contrast, an emotion cluster that is represented by a language with fewer lexical items is likely to have a coarser division of the conceptual space. In this case, the meaning of a lexical item is likely to cover a broader area of conceptual space and hence include lexical items in languages that have a more granulated representation of conceptual space as e.g., in Polish złość and gniew, which are prototypically rendered as anger in English or the English polysemous form pride is cross-linguistically linked to Polish more positive duma or hubristic pycha (Wilson \& Lewandowska-Tomaszczyk, 2017).

The circumstances discussed above are reasons why an absolute equivalence status is considered difficult, if not impossible, to achieve in translation. In terms of inter-cluster relationships, it is clear that the proximity of two adjacent emotion clusters influences the meaning of emotions in these respective clusters. For example, an element of terror is likely to be more salient in repulsion if the fear and disgust clusters have a greater degree of conceptual proximity in the particular language.

It is important to note that the conceptual structure of emotion concepts is influenced by a plethora of direct contextual factors. However, this notwithstanding, it is important to underscore the influence of culture on the conceptual representation of emotions. Emotion concepts, similar to other concepts, are based on overarching cultural representations that are derived from social interactions within a cultural group and which are internalised in parallel with more idiosyncratic components (Sharifian, 2015). The specific cultural influences in this respect include religion, face, honour, power distance, in other words, a plethora of all cultural-linguistic conditions characterizing particular emotion events (Lewandowska-Tomaszczyk \& Wilson, 2013). And yet, the role of individual psychological and aesthetic factors cannot be underestimated, which is evidenced in translators' choices in rendering literary texts, in which emotions and emotionality are not expressed in terms of monolexical emotion terms such as love, fear, disgusting or adorable. Although such monolexical terms have no direct one-to-one equivalents in other languages either - it's sufficient to quote possible English translational equivalents of Polish mitość as affection, fondness, caring, lust, etc. (Lewandowska-Tomaszczyk \& Wilson, 2018) - the translational asymmetries are particularly salient when emotionality and the type of feelings are left unnamed and grow more nuanced and inferred.

\section{Translators' identity}

The problem as to whether our human identity is to be understood in more essentialist terms or whether identity is rather dynamic and subject to change, 
cannot be satisfactorily answered in detail. Our analyses (e.g., LewandowskaTomaszczyk, 2014) support rather a more essentialist interpretation of the identity core substance, shaped by individual earlier life histories and experiences with an area of the dynamicity potential, which is substantiated in terms of emergent attributes. They are situational and regulated by context-specific criteria.

The major identity change affecting translators is the development of plurilinguistic and pluricultural identities. These concepts seem to be representative of a general trend in present-day studies which take identity to be "co-constructed, negotiated and transformed on an ongoing basis by means of language" (Jackson, 2008, p. 35). We thus propose in the present study that the translator's identity is a dynamic cluster of personal, linguistic and cultural properties, which are only partly stable, while in its larger part - subject to change and transformations as a consequence of continuous long-term contacts with a different language and culture.

\subsection{Linguistic identity}

Carol Ann Duffy, a contemporary British poet and playwright, wrote a poem about experiencing another country, a foreign language and its culture, which seems to be a particularly apt expression of the translator's feelings and thoughts when experiencing the presence of two distinct languages in the context of what seems to be identical reality:

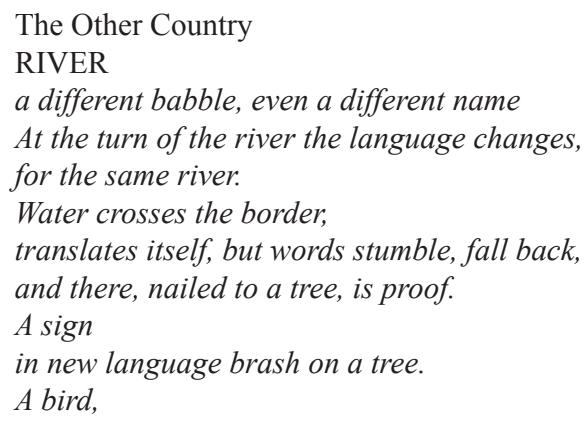

The ordinary things one sees around, a river, water, a bird, do not only have different names but start speaking a different language, 'babble differently', while crossing the border. They themselves are making an attempt to translate themselves into a 'new language' but distant foreign words they produce stumble and fall back, failing.

The definition of linguistic identity is not only difficult for poets - it is even more troublesome for linguistics and translation theories. Attempts to define it as a combination of language expertise, language affiliation, and language inheritance, a relationship between one's sense of self and a means of communication, making reference to multiple language practices, in different contexts, or else 
mixing up languages or introducing lexical and other loans, primarily in spoken interaction - are a few of the current definitional attempts.

We can thus try and repeat, after Block (2007, p. 27), that plurilinguistic identity involves, "socially constructed, self-conscious, ongoing narratives that individuals perform, interpret and project in dress, bodily movements, actions and language". What can then be assumed with no threat of error is that linguistic identity is in fact part of larger cultural identity, equally pertinent to define and understand in the context of translation and translators.

\subsection{Cultural identity}

Numerous existing definitions of culture, current in European thinking from the beginnings of the eighteenth century, e.g., Kluckhohn and Kelly (1945) and Hofstede (1984), emphasize either human thought and embodiments, symbols used or human achievements. The definition of culture proposed here, extending Kroeber \& Kluckhohn (1952), assumes that the constitutive properties of culture include patterning, i.e., repeatedness and structural essence in terms of thought, language, and behavior, with a special position of emotionality, the shareability of such attributes among a given community members, learnability and cultural transmission between generations, in terms of patterns, symbols and signs, as well as cultural imagery, its embodiments in human achievement, in thought and in artifacts.

One of the values combined with culture is the idea of identity, considered a psychological consequence of the interrelationship between various aspects of an individual at regional, social, historical, corporate, and a number of other levels ${ }^{2}$. Each of the aspects co-occurs with a number of parameters, such as social class, generation and gender parameters, ethnicity, religion, and language, as well as emotionality expressiveness and evaluation. All of them create a unique cluster of properties constituting one Gestalt of a particular individual identity. Nevertheless, under the influence of the translator's contact with a new language and culture, his/her reactions, behavior and judgments change.

As discussed in the first section of the present paper, language and other semiotic signs only partly name surrounding objects and events, other parts of the message remaining implicit, either shared or not shared by the interactants. Messages can also be shared on a general communicative level but vary in detail. A new entity which evolves from different input can be a new, trans, value - which involves a construct composed of the two input ideas, which is not a simple sum of the original, native and foreign identities, but rather a system of trans-cultural patterns of thought and behavior (Lewandowska-Tomaszczyk \& Tomaszczyk, 2012), integrative and overlapping but also involving subjectivity and individualism.

The dimensions collocationally related to the English form identity and the

\footnotetext{
2 This part of the section is based on Lewandowska-Tomaszczyk (2019).
} 
corresponding Polish form tożsamość as presented in the lists below, have been generated in this study from the British National Corpus and the National Corpus of Polish (nkjp.pl)

I. Adjectival collocates of Eng. identity

\begin{tabular}{|c|c|c|c|c|}
\hline$\#$ & Collocate & POS & A & TTEST \\
\hline 1 & national & AJ\% & 150.0 & 11.02 \\
\hline 2 & cultural & AJ\% & 96.0 & 9.53 \\
\hline 3 & corporate & AJ\% & 82.0 & 8.85 \\
\hline 4 & personal & AJ\% & 90.0 & 8.75 \\
\hline 5 & social & AJ\% & 92.0 & 7.84 \\
\hline 6 & separate & AJ\% & 62.0 & 7.47 \\
\hline 7 & sexual & AJ\% & 46.0 & 6.38 \\
\hline 8 & individual & AJ\% & 50.0 & 6.30 \\
\hline 9 & ethnic & AJ\% & 41.0 & 6.25 \\
\hline 10 & racial & AJ\% & 38.0 & 6.07 \\
\hline 11 & true & AJ\% & 50.0 & 6.06 \\
\hline 12 & numerical & AJ\% & 35.0 & 5.86 \\
\hline 13 & mistaken & AJ\% & 29.0 & 5.35 \\
\hline 14 & new & AJ\% & 98.0 & 5.30 \\
\hline 15 & common & AJ\% & 40.0 & 5.17 \\
\hline 16 & strong & AJ\% & 37.0 & 5.04 \\
\hline 17 & collective & AJ\% & 27.0 & 5.01 \\
\hline 18 & bourgeois & AJ\% & 23.0 & 4.71 \\
\hline 19 & distinct & AJ\% & 24.0 & 4.64 \\
\hline 20 & European & AJ\% & 32.0 & 4.27 \\
\hline
\end{tabular}

II. Adjectival collocates of Pol. tożsamość 'identity'

\begin{tabular}{|c|c|c|c|cc|}
\hline$\#$ & Collocate & POS & A & \multicolumn{2}{|c|}{ TTEST } \\
\hline 1 & narodowy & adj & 653.0 & 24.91 & 'national' \\
\hline 2 & swój & adj & 773.0 & 22.20 & 'one's own' \\
\hline 3 & własny & adj & 560.0 & 22.17 & 'own' \\
\hline 4 & nasz & adj & 325.0 & 12.72 & 'our' \\
\hline 5 & kulturowy & adj & 125.0 & 11.00 & 'cultural' \\
\hline 6 & potwierdzający & adj & 106.0 & 10.19 & 'affirmative' \\
\hline 7 & płciowy & adj & 73.0 & 8.47 & 'sexual' \\
\hline 8 & europejski & adj & 111.0 & 8.28 & 'European' \\
\hline 9 & prawdziwy & adj & 76.0 & 7.10 & 'genuine' \\
\hline 10 & nowy & adj & 179.0 & 6.92 & 'new' \\
\hline 11 & polski & adj & 159.0 & 6.76 & 'Polish' \\
\hline
\end{tabular}




\begin{tabular}{|l|c|l|l|ll|}
\hline 12 & negatywny & adj & 52.0 & 6.67 & 'negative' \\
\hline 13 & etniczny & adj & 44.0 & 6.51 & 'ethnic' \\
\hline 14 & lokalny & adj & 55.0 & 6.30 & 'local' \\
\hline 15 & religijny & adj & 47.0 & 6.22 & 'religious' \\
\hline 16 & seksualny & adj & 44.0 & 6.06 & 'sexual' \\
\hline 17 & indywidualny & adj & 49.0 & 6.04 & 'individual' \\
\hline 18 & chrześcijański & adj & 42.0 & 6.04 & 'Christian' \\
\hline 19 & zbiorowy & adj & 41.0 & 5.98 & 'collective' \\
\hline 20 & żydowski & adj & 42.0 & 5.88 & 'Jewish' \\
\hline 21 & kolektywny & adj & 30.0 & 5.45 & 'collectivist' \\
\hline
\end{tabular}

While the English data present nation, culture, and individualism, to be the major parameters of the identity concept on the one hand and personality, and ethnicity on the other, in the Polish data, the prevailing dimensions of Polish tożsamość 'identity' are nation, ethnicity (one's own, Polish, ours, Jewish), collectivism, sex and religion (Christian). These differences between sets of collocates in different languages are argued in the present paper to be a particularly revealing material to appreciate Polish culture-specific perceptions and judgments of other cultures and transformations that take place during contacts with foreign texts and cultures. In dynamic contacts with a Target Language and Target Culture, the translator transforms their own personality, knowledge, world perception and the perception of another language and culture.

A special position within those attributes is occupied by emotions and their culture- and language-specific character (Wilson \& Lewandowska-Tomaszczyk, 2018). For that reason the properties of one's own, individual identity, emotional sensitivity and taste, will function as one of the strongest identity attributes for translators, particularly those who work with literary language. Their linguistic and cultural identities develop into plurilinguistic and pluricultural networks.

\section{Translators' choices}

\subsection{Linguistic constraints and translator's strategies}

The main categorization difference between distinct types of reconceptualization lies between a category associated with a particular language type, i.e., a typologicallybased re-conconceptualization, in other words, all changes and transformations between SL and TL which express distinct linguistic constraints and pressures, associated with one language but not with the other one. The other category, which can be adequately considered synonymous with the concept of translator strategies, is associated with the translator's subjective preferences towards particular linguistic choices. Such typologically-based reconceptualization patterns (constraints) can be exemplified by Eng. medio-passive voice and Polish reflexive verb patterns as in 
e.g., Boring, grumpy men annoy easily and the corresponding form It is easy to annoy boring, grumpy men. The Polish equivalents Łatwo jest zirytować nudnych, zrzędliwych mężczyzn or Nudni, zrzędliwi mężczyźni łatwo się irytuja present a syntactic translational pressure, preset in Polish but, at the same time, it is one selected from a number of possible constructions in the translator's repertory e.g., Nietrudno zirytować nudnych, zrzędliwych mężczyzn or Nie jest trudno, aby nudni, zrzędliwi mężczyźni szybko sie zirytowali with the use of the corresponding impersonal, reflexive, etc., constructions, which retain a similar (though not identical) meaning. In cross-linguistic comparisons what is conventionally observed are weakly commensurable categorical hierarchies in language and, rooted in them, a dynamic displacement of senses (Lewandowska-Tomaszczyk, 1987).

It goes without saying that it is the linguistic constraints primarily that are coercive on the involuntary translators' choices in a Target Language. The genuine translators' strategies on the other hand do not form a uniform category. They are relevant to and conditioned by the type of text and discourse constraints. In specialized languages, the terminological requirements and the field ontology imposes a particular set of terminological requirements and any departure from the norm has to be clearly justified. In the language of literature on the other hand, a fuller portrayal of the translator's personality, sensitivity and preferences can be demonstrated, and the next section of the present paper focuses on a few of such selected choices.

\subsection{The Great Gatsby in Polish}

Gatsby, the main character of F. Scott Fitzgerald's novel The Great Gatsby, addresses males with whom he interacts with the phrase old sport. The phrase is a friendly term of endearment, which was typically used by English gentleman of high society in the early twentieth century and addressed to other gentlemen. F. Scott Fitzgerald uses the term to portray an image of an English aristocrat from an affluent family, who attended Oxford and is considered "old money", unlike Gatsby himself, associated with 'new money'. The phrase old sport then has a function - to legitimize Gatsby as a wealthy, charismatic English aristocrat, particularly attractive for Daisy Buchanan, a married woman from an affluent background. In other words, the phrase old sport can be considered a dominant translational mode for Gatsby's personal characterization ${ }^{3}$.

In the three different translations of The Great Gatsby into Polish, almost contemporaneous - one from the year 2012, translated in 1962 and two from 2013 - the phrase is dealt with in different ways.

3 For the concept of Pol translational dominant 'dominant mode' in the sense of the most significant part of the original SL text that cannot be left out untranslated in a TL, cf. Bednarczyk (1999). 
(1)

I can't talk now, old sport

1. nie mogę teraz rozmawiać mój drogi (Ariadna Demkowska-Bohdziewicz, 2012/1962, p. 102).

2. Tak, niestety nie mogę teraz rozmawiać (literary editing Kazimierz Cap, 2013, p. 96).

3. Nie mogę rozmawiać stary druhu (Jacek Dehnel, 2013, p. 115) [(old) friend, mate, comrade, scout] 'old buddy, old man, old pal' [emphasis added].

(2)

Don't talk so much old sport. Play

1. Nie mów tak dużo, rozkazał Gatsby. Graj (p.103).

2. Graj, zarządził bezlitosnym głosem jego oprawca (p. 97).

3. Nie gadaj tyle, stary druhu - rozkazał mu Gatsby. - Graj! (p. 116) [emphasis added].

Considering the marked discourse significance of the discussed phrase, leaving it out in the TL version of the novel seems not so much one of the possible translation strategies but rather a case of incompetence. The role of the phrase is clearly understood only by Jacek Dehnel, translator of the third version. DemkowskaBohdziewicz occasionally uses the address form mój drogi, Polish equivalent of 'my dear' as in example (1.1.). The form mój drogi appears also in the translation 1.2. On the other hand, even though Dehnel does appreciate the social role of such a form of address and uses it in the novel as a regular phrase, the solution he proposes is debatable. Dehnel's equivalent is stary druhu. To examine the use and distribution of the phrase in Polish the PELCRA corpus of Polish data was consulted. A few examples of the use of the phrase stary druhu demonstrate its contexts:

(3)

Orson wyrwał kartkę z maszyny i przeczytał na głos, to co napisał. Gdy skończył, stanął przed lustrem.

- No i co sądzisz, Rose ... stary druhu?

Orson pulled out the sheet from the typewriter and read aloud what he wrote. When he finished, he stopped in front of the mirror.

- And what do you think, Rose ... stary druhu? [emphasis added].

(4)

- Nie idzie nam o ciebie, stary druhu, ale o zagadnienie. Jak to wygląda z perspektywy czasu? Aza-liż brałbyś dzisiaj czy strzelałbyś?

- A on co, bez rodziny?

- Ma żonę.

It does not concern you, stary druhu, but an issue. How does it look like from the time perspective? We enquire whether today you would take them [get the enemy and capture] or would you shoot [them]?

- And is he with no family?

- He's got a wife [emphasis added]. 
(5)

Tłumaczyłem mu: „A może te ilustracje na zadany temat spełniają jakąś rolę? Pociesz mnie, stary druhu".

I was trying to explain to him: ,and perhaps these illustrations on given subject fulfill some role? Comfort me, stary druhu"' [emphasis added].

Used in the context of old friendship or acquaintance the Polish phrase, sounding rather archaic (or jocular) at present, does not possess this higher status marking as the original English one, used among aristocrats and Oxon graduates in high circles contexts. It may also be more emotional as used in the contexts of (3) to (5) than the English original. Furthermore, the Polish phrase is also used in a number of de-emotive contexts, among scouts and party members, which makes it sound rather egalitarian than exclusive. Nevertheless, the fact that Dehnel noted the phrase and found out about its social significance, unlike the other two translators, tells the reader of his linguistic sensitivity and erudition. Forms of address always pose problems in translation. Suffice to add that in numerous translations of William Shakespeare's Hamlet, rather exotic forms of address, when compared to the original, and quite obsolete nowadays, are introduced in Polish versions by various translators ${ }^{4}$. The English original forms in

(6)

Polonius: He closes you in this consequence;

'Good sir,' or so; or 'friend,' or 'gentleman',

have been translated either as fully domesticated historic 'mospanie, wasze, przyjacielu' (Komierowski in 1857), 'Mości dobrodzieju, Mój miły panie, Widzisz waćpan' (Paszkowski in 1862), which correspond to the historic convention of the $19^{\text {th }}$ century, or else as the most contemporary version by Barańczak (in 1990) 'Mój przyjacielu, dobry człowieku, panie' corresponding to 'My friend, good man, Sir'.

Dehnel is a very conscientious translator. Unlike the other two translators, Dehnel provides definitions and explains the phrases and circumstances which might not be familiar to the reader. At the beginning of chapter two Fitzgerald makes reference to a valley of ashes (p. 20). While the two translators (1. and 2.) simply use the phrase in its Polish sense 'dolina popiołów', Dehnel provides a lengthy footnote describing its origin with reference to an area between West Egg and New York city.

Not only does Jacek Dehnel issue the readers with more extensive background by offering them clues to achieve a fuller grasp of the implicit message present in the SL text, but is also ready to extend his own knowledge and sensitivity to develop wider aesthetic and conceptual appreciation of the original text. The last of the

\footnotetext{
4 As cit. in Lewicki (2000, pp. 46-62); repeated also in Górski (2013, pp. 146-147).
} 
interesting differences between the three translated versions of The Great Gatsby discussed in the present study involves the fact that in two of them (1. and 2.) the epigraph - a poem introducing the novel - is left out unmentioned in the translations and it is only Jacek Dehnel who considers the epigraph sufficiently significant to retain in the translated version. The poem is supposed to be authored by a fictitious poet, a minor persona of one of the earlier novels by Fitzgerald, modelled on one of the author's Princeton friends.

(7)

Then wear the gold hat, if that will move her;

If you can bounce high, bounce for her too,

Till she cry 'Lover, gold-hatted, high-bouncing lover,

I must have you!

Thomas Parke D'Invilliers

Jacek Dehnel proposes a rhymed version of the poem in Polish:

(6a)

Gdy ją to wzrusza - noś złotą czapkę,

Gdy latać umiesz - to dla niej leć!

Aż krzyknie: miły, złotoczapkowy, lotny mój

Musze cię mieć!

Miły, podaj mi łapke,

Although the translation is faithful to the SL text, Dehnel forces in an extra line as it seems to keep the rhyme (czapke 'hat' - tapkę 'little paw'). The inserted line brings about a friendly, though mockingly light and jocular atmosphere, in terms of (conventionally metaphorical): podaj mi lapke, (koteczku) 'Give me your little paw, (kitten)!'. When addressed to a loved one, it trivializes the emotional tenor and arousal of the original. But in fact, this is what the story is about. What Dehnel does is not thoughtlessly insert a completely dispensable rhymed line into the poem. This supplement can be considered rather a well-thought-out maneuver - Gatsby, adopting his "Oxford man" persona is - as the poem portrays him in "this image of a 'gold-hatted, high-bouncing lover' - not an emotion-driven passionate lover but "clownish at best and completely absurd at worst" (Wulick, 2019)

In translating The Great Gatsby, Dehnel develops as a connoiseur of a New England nouveau riche culture specialist and an expert analyst of the language and manners of the period. The translator most strongly - when contrasted with other translators - emphasizes the witty message of the story, in which emotions put on a pedestal, transform into platitudes and trite.

\footnotetext{
5 Retrieved October 1, 2019, from https://blog.prepscholar.com/the-great-gatsby-epigraphbeginning-analysis.
} 


\section{Equivalence}

The final point discussed in the present study, subsuming consequences of the analysis of the data above, concerns the function and definition of the major concept in translation studies, namely translational equivalence.

In Lewandowska-Tomaszczyk $(2013,2019)$ a typology of translational cluster equivalence ${ }^{6}$ is proposed, which embraces the following categories:

I. Trivial equivalence (with full(er) commensurability) as in Jim loves youJim kocha cię.

II. Non-trivial equivalence

a. Derived (equivalence from corresponding inter-linguistic clusters, also metaphorical and metonymic) as in He is afraid of dogs - Boi się psów; lit. 'He fears himself of dogs'; He was frightened - Strach go obleciat; lit. 'Fear overwhelmed him'

b. Extended (equivalence embracing corresponding causes, results, and/ or presuppositions) He displayed great cowardice - Zdradzat okropny strach; lit. '(He) displayed great fear'

c. Creative (extending beyond conventional linguistic and cultural limits)

While the derived and extended equivalence types are frequent and wellexploited in translation practice, a new version of Joseph Conrad's Heart of Darkness, by Dukaj (Serce ciemności, 2017), bears the properties of creative equivalence in a translation, or rather in the polonization, as Dukaj insists, of the original. While some critics describe Dukaj's work as "an experiment. [...], the most significant and boldest literary project of the year" ", others blame Dukaj ${ }^{8}$ for "tearing Conrad's text out of all emotions, also of its awe or dread, as even that disappears in the flood of exclamations".

And yet, Dukaj's text, a fragment of which is adduced below, contrasted with Aniela Zagórska's translation (Jadro ciemności, 1930) and confronted with the original (Conrad, 1899), portrays Dukaj as an unconventional persona, whose interpretation uncovers new emotional layers of literature interpretation:

Cf. Lewandowska-Tomaszczyk (2017) for the concept of cluster equivalence.

7 Quoted in the original Polish version in Lewandowska-Tomaszczyk (2019) „najważniejszy i najodważniejszy projekt literacki roku!”, „Projekt-obsesja, wyzwanie, które prześladowało Jacka Dukaja od kilkunastu lat, a zarazem eksperyment z przekładalności prozy i przeżycia. To nie jest nowe thumaczenie, to coś znacznie więcej” (Justyna Sobolewska, 14. October, 2017). Retrieved November 10, 2018, from http://www.polityka.pl/tygodnikpolityka/kultura/ksiazki/1727056,1,recenzja-ksiazkijoseph-conrad-jacek-dukaj-serce-ciemnosci.read.

${ }^{8}$, ,[Dukaj]...odarł tekst Conrada z jakichkolwiek uczuć, również z poczucia grozy, bo nawet ona ginie w zalewie wykrzykników." 
(8)

Black shapes crouched, lay, sat between the trees leaning against the trunks, clinging to the earth, half coming out, half effaced within the dim light, in all the attitudes of pain, abandonment, and despair (Joseph Conrad).

(8a)

Czarne kształty czołgały się, leżały, siedziały między drzewami, opierając się o pnie, Śmierć, Choroba, Głód tuliły się do ziemi — to widzialne, to przesłonięte mętnym półmrokiem - we wszelkich możliwych pozach wyrażających ból, zgnębienie i rozpacz (Aniela Zagórska).

(8b)

Leżą siedzą kucają konają ${ }^{9}$, ciemne kształty w ciemności - z ziemi, w ziemi, do ziemi ${ }^{10}$ przytuleni, wczepieni, wypływają z ciemności w półmrok - oblicza bólu, mięso rozpaczy i z półmroku w ciemność - gdzie są już tylko czarnymi formami choroby i głodu - oni konają konają konają ${ }^{11}$ (Jacek Dukaj).

While Zagórska's version presents a regular derived equivalence, though more verbose and direct when compared to the English original, Dukaj's polonization climbs to reach the limits of approximate equivalence. It involves the magnifying of the original, richly emotional, perlocutionary effects of the metonymic senses of threat, fear, terror and death. Embedded in rhythmic punctual repetitions (ft 9, 10 and 11), co-temporality of acts and effects ${ }^{12}$, emotions are not conveyed directly. Their senses are re-conceptualized - rooted in the inference of lexical meanings, dynamics of sentence equivalents and unusual punctuation.

\section{Conclusion}

A new definition of translation as creative re-conceptualization of the original, drawing inspiration and making informed choices from spaces of meanings might also - to a large extent - determine a creative identity of translators of literary texts in particular. In the case of such translation practice, it is the translator's personal identity, sense of emotionality, predilections and preferences, as well as the degree of professional engagement and assiduity that contribute to the quality of the final effect.

The identity properties discussed in the first part of the present study indicate the important position for one's own, personal characterization of this concept, local and individual for a particular person. Spaces of meaning for each are different, partly only constrained by conventional linguistic rules and translation strategies.

\footnotetext{
9 Leża siedza kucaja konaja ' [they're] lying sitting dying crouching down/squatting'

${ }^{10}$ z ziemi, w ziemi, do ziemi - play on the senses of ziemia, polysemous in Polish between earth, soil, ground, land - 'from the soil/earth/ground', w ziemi - 'in the soil', do ziemi 'to/towards/into the soil/ground'.

${ }^{11}$ Oni konaja konaja konaja'they are dying dying dying' (with no commas in Dukaj's version).

12 The use of the present tense, which corresponds semantically to English durative or (persistently) iterative actions in this context.
} 
It goes without saying that this liberty of drawing from the unconventional is never unconstrained though, as in the case of emotional senses the equivalence tolerance threshold (Lewandowska-Tomaszczyk, 2012) is not easy to define.

The informed choices from spaces of meanings in the case of specialist languages on the other hand (Lewandowska-Tomaszczyk, 2017), are limited by terminological boundaries and domain-specific ontologies. But even there, in such restricted-domain contexts, there is room for new meaning areas and new terminological spaces. This subject though needs to wait for an exploration in a separate study.

\section{References}

Bednarczyk, A. (1999). Wybory translatorskie. Modyfikacja tekstu literackiego w przekładzie i kontekst asocjacyjny, Łódź: Wydawnictwo Uniwersytetu Łódzkiego.

Block, D. (2009). Identity in applied linguistics: The need for conceptual exploration. In L. Wei, \& V. Cook (Eds.), Contemporary applied linguistics: Vol. 1 (pp. 215-232). London: Continuum.

Conrad, J. (1899). Heart of Darkness. Edinburgh: Blackwood's Magazine.

Conrad, J. (1930/1899). Jądro ciemności (A. Zagórska, Trans.). Kraków: Dom Książki Polskiej Spółka Akcyjna.

Conrad, J. (2017/1899). Serce ciemności (J. Dukaj, Polonized). Kraków: Wydawnictwo Literackie.

Dawkins, R. (2005). Why the universe seems so strange. Retrieved March 5, 2016, from https:// www.ted.com/talks/richard_dawkins_on_our_queer_univers.

Górski, T. P. (2013) . Polskie przektady „Hamleta” Williama Shakespeare'a. Polska. Wrocław: Akademia Nauk, Oddział we Wrocławiu.

Hall, E. T. (1989). Beyond culture. New York: Anchor Books.

Hofstede, G. (1984). National cultures and corporate cultures. In L. A. Samovar, \& R. E. Porter (Eds.), Communication Between Cultures. Belmont, CA: Wadsworth.

Jackson, J. (2008). Language, identity and study abroad: sociocultural perspectives. London: Equinox.

Katz, J. J. (1978). Effability and Translation. In F. Guenthner, \& M. Guenthner-Reutter (Eds.), Meaning and Translation. Philosophical and Linguistic Approaches (pp. 191-234). New York: University Press.

Kluckhohn, C., \& Kelly, W. H. (1945). The concept of culture. In R. Linton (Ed.), The Science of Man in the World Crisis (pp. 78-105). New York: Columbia University Press.

Kroeber, A. L., \& Kluckhohn, C. (1952). Culture: A critical review of concepts and definitions. Cambridge University: Papers of the Peabody Museum of American Archeology and Ethnology: Vol. 47. Cambridge: Cambridge University Press.

Lakoff, G. (1987). Women, Fire and Dangerous Thing: What Categories Reveal about the Mind. Chicago: Chicago University Press.

Langacker, R. W. (1987). Foundations of Cognitive Grammar: Vol. 1. Stanford: Stanford University Press.

Langacker, R. W. (1991). Foundations of Cognitive Grammar: Vol. 2. Stanford: Stanford University Press.

Lewandowska-Tomaszczyk, B. (1987). Conceptual Structure, Linguistic Meaning, and Verbal Interaction. Łódź: Wydawnictwo Uniwersytetu Łódzkiego.

Lewandowska-Tomaszczyk, B. (2010). Re-conceptualization and the emergence of discourse meaning as a theory of translation. In B. Lewandowska-Tomaszczyk, \& M. Thelen (Eds.), Meaning in Translation (pp. 105-148). Frankfurt am Main: Peter Lang Verlag. 
Lewandowska-Tomaszczyk, B. (2012). Approximative Spaces and the Tolerance Threshold in Communication. International Journal of Cognitive Linguistics, 2, 2-19.

Lewandowska-Tomaszczyk, B. (2014). Emergent Group Identity Construal in Online Discussions: A Linguistic Perspective. In F. Zeller, C. Ponte, \& B. O’Neill (Eds.), Revitalising Audience Research: Innovations in European Audience Research (pp. 80-105). London: Routledge.

Lewandowska-Tomaszczyk, B. (2017). Cluster Equivalence, General Language, and Language for Specific Purposes. In M. Grygiel (Ed.), Cognitive Approaches to Specialist Language (pp. 384-418). Newcastle upon Tyne: Cambridge Scholars Publishing.

Lewandowska-Tomaszczyk, B. (2017a). Partial perception and approximate understanding. Research in Language, 15(2),129-152.

Lewandowska-Tomaszczyk, B. (2019). Czy ekwiwalencja translatorska jest urojeniem? In M. Woźnicka, A. Stolarczyk-Gembiak, \& M. Trojszczak (Eds.), Zbliżenia 5: Językoznawstwo - Literaturoznawstwo - Translatologia (pp. 267-283). Konin: Wydawnictwo Państwowej Wyższej Szkoły Zawodowej w Koninie.

Lewandowska-Tomaszczyk, B., \& Tomaszczyk, J. (2012). "We in the Union": A Polish Perspective on Identity. In P. Bayley, \& G. Williams (Eds.), European Identity: What the Media Say (pp. 224-257). Oxford: Oxford University Press.

Lewandowska-Tomaszczyk, B., \& Wilson, P. A. (2013). English fear and Polish strach in contrast: GRID approach and cognitive corpus linguistic methodology. In J. J. R. Fontaine, K. R. Scherer, \& C. Soriano (Eds.), Components of emotional meaning: A sourcebook (pp. 425-436). Oxford: Oxford University Press.

Lewicki, R. (2000). Obcość w odbiorze przekładu. Lublin: Wydawnictwo Uniwersytetu Marii Curie-Skłodowskiej.

Michelis, A., \& Rowland, A. (Eds.). (2003). Choosing Tough Words: The Poetry of Carol Ann Duffy. Manchaster \& New York: Manchaster University Press.

Scott, F. (1991/1925). The Great Gatsby. London: Everyman's Library.

Scott, F. (2012/1962). Wielki Gatsby (A. Demkowska-Bohdziewicz, Trans.). Poznań: Dom Wydawniczy Rebis.

Scott, F. (2013/1925). Wielki Gatsby (K. Cap, Literary Editing). Warszawa: Bellona.

Scott, F. (2013/1925). Wielki Gatsby (J. Dehnel, Trans.). Kraków: Wydawnictwo Znak.

Sharifian, F. (2017). Cultural Linguistics. Amsterdam: Benjamins.

Sossinsky, A. B. (1986). Tolerance Space Theory and Some Applications. Acta Applicandae Matematicae, 5(2), 137-167.

Sperber, D., \& Wilson, D. (1986). Relevance. Oxford: Blackwell.

Wilson, P. A. \& Lewandowska-Tomaszczyk, B. (2017). Pride in British English and Polish: A Contrastive Linguistic Perspective. In F. Sharifian (Ed.), Advances in Cultural Linguistics, 247-288. DOI: 10.1007/978-10-4056-6 12.

Wilson, P. A., \& Lewandowska-Tomaszczyk, B. (2019). Cognitive Structure and Conceptual Clusters of Emotion Terms. Filozofia i Nauka. Studia filozoficzne i interdyscyplinarne, 7(1), 91-123.

Wulick, A. (2019). Best Analysis: The American Dream in The Great Gatsby. PrepScholar, 17. March.. Retrieved October 1, 2019, from https://blog.prepscholar.com/the-great-gatsby-american-dream. 